\title{
The Question of St. Jerome's Translation ex Hebraica veritate: the Example of Deut. 8:15*
}

\section{Łukasz Krzyszczuk}

University of Wrocław, Institute of Classical, Mediterranean and Oriental Studies, Department of Ancient Near East and Biblical Tradition,

21, ul. Komuny Paryskiej, Wrocław, 50-451, Poland; lukasz.krzyszczuk@uwr.edu.pl

Krzysztof Morta

University of Wrocław, Institute of Classical, Mediterranean and Oriental Studies, Department of Ancient Near East and Biblical Tradition,

21, ul. Komuny Paryskiej, Wrocław, 50-451, Poland; krzysztof.morta@uwr.edu.pl

For citation: Łukasz Krzyszczuk, Krzysztof Morta. The question of St. Jerome's translation ex Hebraica veritate in the example of Deut. 8:15. Philologia Classica 2021, 16 (2), 241-261.

https://doi.org/10.21638/spbu20.2021.207

This article offers yet another opinion concerning the $18^{\text {th }}$-century controversy surrounding St. Jerome's level of knowledge of Hebrew and his Old Testament translation from the Hebrew truth (ex Hebraica veritate). Assurances that Jerome's Latin rendition is based directly on the Hebrew biblical books made by the monk himself and by his contemporaries are widely challenged. Jerome's testimony is not entirely credible as he tended to confabulate and prevaricate. Having retraced this dispute about the Stridon-born scholar, the authors of this article subject verse 8:15 of the Book of Deuteronomy to a thorough analysis. It is a peculiar and important fragment for the ongoing discussion due to the appearance of the Hebrew word Greek version (LXX), it had been translated as di $\psi \alpha$ ("dry land"). What is crucial here is the fact that a similar form, $\delta ı$ ác, exists in the Greek language. It is a term used for a venomous snake. Potentially mistaking "dry land" for a "snake" in the Hebrew language is not possible. That is why in Jerome's translation of the Bible from the Hebrew truth such an error should not have occurred. Meanwhile, we can find exactly that mistake in the scholar's rendition. In his

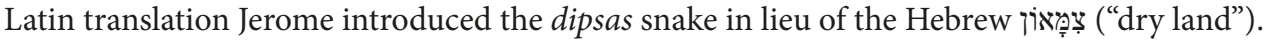
This article aims to explain why, in this very spot, the translator departed from the Hebrew original.

Keywords: St. Jerome, Vulgate, Book of Deuteronomy, translation studies, snakes, Hebraica veritas.

Around 390 A. D. St. Jerome gave up on his rendition of the Greek Septuagint into Latin and started to translate the text of the Old Testament, as he says himself, directly from Hebrew. ${ }^{1}$ Jerome claims, rather explicitly, that in his translation work he is directed

* We would like to express our deep gratitude to Professor Alexander Gavrilov for his kind comments and helpful philological hints.

${ }^{1}$ Cf. Hieron. Praef. in Libro Regum: Hic prologus Scripturarum quasi galeatum principium omnibus libris, quos de hebraeo vertimus in latinum, convenire potest [...] Et cum intellexeris quod antea nesciebas, vel interpretem me aestimato, si gratus es, vel $\pi \alpha \rho \alpha \varphi \rho \alpha \sigma \tau \eta \dot{v}$, si ingratus, quamquam mihi omnino conscius non sim mutasse me quippiam de hebraica veritate. Certe si incredulus es, lege graecos codices et latinos et

(C) St. Petersburg State University, 2021 
by the Hebrew truth (Hebraica veritas ${ }^{2}$ ) and specifies that it is the Hebrew original he adheres to and not the Greek hexaplar ${ }^{3}$ Bible-based renditions. St. Jerome therefore drifts away from the LXX ${ }^{4}$ towards the meanings and significations that are carried by the $\mathrm{He}$ brew text, already known in his times. ${ }^{5}$ He does that, as he asserts, thanks to his command of the Hebrew language and in reference to the Hebrew version, on which he based his Old Testament translation. ${ }^{6}$

Jerome's level of knowledge of biblical Hebrew is a matter under discussion among scholars studying his works. If we took into consideration the Vulgate's father's words, we would have to assume that St. Jerome was exceptionally fluent in this language. Let us then have a look at what his own works tell us about Jerome's study of the Old Testament's language. The Vulgate's father's first encounter with Hebrew occurred as early as around 375 A. D. during his 18 -month stay in the desert of Chalcis, ${ }^{7}$ where he began his education with a Jew who had converted to Christianity. ${ }^{8}$ This first contact with the language did not last long as the Stridon-born scholar had to leave his hermitage after less than two years. What is more, Jerome was also at this time learning Greek, copying manuscripts for his library, corresponding with his friends and finishing the now lost First Commentary on Obadiah. ${ }^{9}$ The scholar was set to renew his Hebrew studies after he settled in the Holy Land, and that supposedly took place approximately between $386-390^{10}$ (this period included a few breaks dedicated to travelling, e. g., to Egypt). His education was partially

confer cum bis opusculis, et ubicumque inter se videris discrepare, interroga quemlibet Hebraeorum cui magis accommodare debeas Fidem, et si nostra firmaverit, puto quod eum non aestimes coniectorem, ut in eodem loco mecum similiter divinarit. In the work De vir. ill. 135 (c. 392/393), Jerome wrote directly: Novum Testamentum Graecae fidei reddidi, Vetus iuxta Hebraicum transtuli. In a letter to St. Augustine of 404 (Ep. 112. 19), Jerome confirms that he has given up his work on translations from Greek in favor of work on the Hebrew text: Illa enim interpretatio septuaginta interpretum est et, ubicumque virgulae, id est obeli, sunt, significatur, quod Septuaginta plus dixerint, quam habetur in Hebraeo, ubi autem asterisci, id est stellae praelucentes, ex Theodotionis editione ab Origene additum est. et ibi Graeca transtulimus, hic de ipso Hebraico, quod intellegebamus, expressimus sensuum potius veritatem quam verborum interdum ordinem conservantes. For more information on the Hebrew translations of St. Jerome, see Rico 2016.

2 Cf. Laato 2021, 495: He thus realized the importance of the 'Hebraica veritas' - that is, the Hebrew original. Beginning in about 390, he translated the whole of the Old Testament from the Hebrew. [...] he often refers to veritas ("truth"; even 'terminus technicus' for original text).

${ }^{3}$ For more on the hexaplar translations of the OT and their influence on the translation ratio of St. Jerome, see Thibaut 1959.

${ }^{4}$ Cf. Hieron. Praef. in Ezram: Edidi aliquid quod non habetur in graeco vel aliter habetur quam a me versum est. Quid interpretem laniant? Interrogent Hebraeos et ipsis auctoribus translationi meae vel adrogent vel derogent fidem.

5 Edmund Felix Sutcliffe wrote about the Hebrew text of the OT in the time of Saint Jerome; see Sutcliffe 1949.

${ }^{6}$ Many years before translating the OT from Hebrew, Jerome adhered to the principle of turning to the original work directly, using a figurative metaphor (Adv. Helvidium 8: Multo purior manare credenda sit fontis unda quam rivi).

7 Chalkis ad Belum (today the archaeological site of Qinnasrīn), popular among hermits in the time of Jerome, is located about $30 \mathrm{~km}$ southwest of Aleppo. On life in this desert, see Hieron. Ep. 14. 1-3, Vita Malchi 3.

8 Cf. Ep. 125. 15.

9 On Commentary on Obadiah, written in his youth, see Hieron. In Abdiam, prol. The short contact with Hebrew did not prevent Jerome from teaching Paula and Blaesilla (for more about the Aventine patricians, friends of St. Jerome, see Zittel 2000) this language after arriving in Rome at the call of Damasus, mentioned in 384 (cf. Ep. 39. 1). However, it could simply be about learning letters and reading, because the result of this study was the ability of Roman friends of the Vulgate's author to sing psalms in Hebrew.

10 Cf. Nautin 1983. 
guided by the Palestinian rabbi Bar-Anina, ${ }^{11}$ who, apart from teaching Hebrew, informed the Monk of Bethlehem about the rabbinic exegetical solutions to the more difficult biblical pericopes. It is possible that before he set about translating the Old Testament (starting from the Books of Samuel and Kings around 390 A.D.), Jerome could have been potentially learning biblical Hebrew for a maximum of 4-5 years. During that period the scholar was, as he says himself, learning and doing his literary work at nights, after his tiring daily chores. ${ }^{12}$ Additionally, his education was interrupted by other responsibilities (for instance, taking care of the Bethlehem monastery, travelling, dogmatic disputes), his frequent ailments ${ }^{13}$ and poor eyesight. This latter hindrance must have been especially troublesome ${ }^{14}$ during his hard work on the Hebrew manuscripts. Jerome's numerous translations of the Old Testament's Books as well as his exegetical works - that required some reflection and peace of mind - were being created very swiftly, frequently at night. ${ }^{15}$ All those factors, i.e., the pace of translation, the late-night work on the handwritten Hebrew text, together with an eye disease, work in the monastery and creating other exegetical pieces, may lead us to a certain degree of scepticism. St. Jerome himself emphasises, however, that in spite of all those impediments, he was able to achieve proficiency in the Hebrew language. In his work entitled Letter against Rufinus (Epistula adversus Rufinum presbyterum Aquileiensem), polemicising with his adversary, Jerome explicitly calls himself a trilingual man:

Ego philosophus, rhetor, grammaticus, dialecticus, hebraeus, graecus, latinus, trilinguis.

"I am a philosopher, a rhetorician, a grammarian, a dialectitian, speaking Hebrew, Greek, Latin - three languages." 16

If we were to take St. Jerome's words uncritically, we should assume that he knew Hebrew so proficiently as to achieve a fluent listening comprehension. In his foreword to his translation of the Book of Tobit (dated around 405-407), the scholar says that he found a Jew who spoke Aramaic and Hebrew fluently, and who orally - ad hoc - was rendering this book to Jerome from Aramaic to Hebrew. And Jerome, simultaneously, was translating it from Hebrew into Latin, dictating the text to a stenographer. All this work

11 Cf. Ep. 84. 3: Rursum Hierosolymae et Bethleem quo labore, quo pretio Baraninam nocturnum habui praeceptorem! More about this figure, impossible to identify among the rabbis of the $4^{\text {th }}$ and $5^{\text {th }}$ centuries, which appears only twice in the writings of St. Jerome, can be found in Opelt 1988.

12 See e. g., Hieron. Adv. Vigilantium 17, Ep. 36. 1; 64. 23; 117. 12; 119. 1.

13 See e. g., Ep. 71. 5; 73. 10; 74. 6.

14 As early as 387 A. D. (i. e., before starting work on the translation of the OT from Hebrew), Jerome mentions his eye disease (In Galatas 3. prol.: Accedit ad hoc quia propter oculorum et totius corpusculi infirmitatem manu mea ipse non scribo). The vision problems appear to be chronic as they are mentioned in later writings as well (In Hiezechielem 7. prol. [414 A. D.]: Accedit ad hanc dictandi difficultatem, quod caligantibus oculis senectute et aliquid sustinentibus beati Isaac, ad nocturnum lumen nequaquam valemus Hebraeorum volumina relegere, quae etiam ad solis dieique fulgorem, litterarum nobis parvitate caecantur).

15 An Aramaic translation of the Book of Judith was to be written overnight: huic unam lucubratiunculam dedi (Praef. in Iudith), Commentary on the Book of Obadiah in two nights (In Abdiam 1. 21). In the introduction to the Commentary on the Letter to the Galatians, he says that he hurriedly dictated 'whatever came to his lips' (In Galatas 3. prol:: quodcumque in buccam venerit). The Commentary on the Ephesians was written at the rate of a thousand verses a day (In Ephesios 2. prol.: sed ad revelanda mysteria Scripturarum, uti verbis pene de trivio, et interdum per singulos dies usque ad numerum mille versuum pervenire, ut coepta in Apostolum explanatio, ipsius Pauli, cuius Epistolas conamur exponere, orationibus compleatur) and the translation of the books of Proverbs, Ecclesiastes and Song of Solomon is known as the tridui opus - three difficult books of poetry that were translated by Jerome in three days.

${ }^{16}$ Hieron. Ep. adv. Rufinum 6. 
was supposedly done in the course of one day (unius diei laborem arripui). ${ }^{17}$ Apart from linguistic fluency, even more surprising is the fact of the oral interpretation of the Old Testament from Aramaic into Hebrew, so from a spoken into an already long-dead language. This would be a case of inverted targumism. We should also look further into what 'Hebrew' did this Jew orally translate the Aramaic Tobit. Was it the northern dialect? ${ }^{18}$ Or maybe the southern Judean dialect, more common in the Old Testament? Or maybe the Jewish interpreter spoke the Mishnaic Hebrew? In giving credence to these revelations, we should acknowledge the Stridon-born scholar not only as an extraordinarily capable translator, but also as a very lucky man to have found such a linguistically fluent Jew. ${ }^{19}$ In light of what Jerome says in the abovementioned foreword to his rendition of the Book of Tobit, it is strange that a few years earlier while translating the Aramaic parts of the Book of Daniel into Latin, the scholar did not need an interpreter. He managed perfectly on his own because, as he claims himself in Daniel's foreword, he can read and understand Aramaic and is only unable to speak the language. ${ }^{20}$

It is difficult therefore to rely on such contradictory testimonies, all the more so as the scholar errs in many places (not to say that he cheats). As we can clearly see, Jerome wants to pass for an outstanding figure of his era and that is the impression his meticulously built-up narration is intended to create. The pace of his intellectual work - many a time performed in tough conditions and against various impediments - as well as his erudition, command of languages (ones no Latinists knew) and studying under the guidance of prominent tutors aim to make the Monk of Bethlehem a figure similar to Origen. Jerome had openly admired the Alexandria-born scholar ${ }^{21}$ (up until the controversies around Origen broke out). He ventures so deeply into showing himself as a vir doctus (a scholarly man), a great man of letters, that he refers to reading non-existent works by Pythagoras - a fact that Rufinus of Aquileia makes a point of and ultimately reproaches the Stridon-born monk for this. ${ }^{22}$ Moreover, his narcissism and oversensitivity about himself are clearly seen in Jerome's constant 'playing it safe' and explanations to the readers of his works or translations (that he should not be judged harshly because he did not have much time), and in his spasmodic reactions to any criticism. ${ }^{23}$

${ }^{17}$ Hieron. Praef. in Tobiam: Et quia vicina est Chaldaeorum lingua sermoni Hebraico utriusque linguae peritissimum loquacem reperiens, unius diei laborem arripui et quidquid ille mihi Hebraicis verbis expressit hoc ego accito notario sermonibus Latinis exposui.

18 See Rendsburg 1990.

19 Cf. Graves 2007, 89-90.

20 Hieron. Praef. in Danielem: Usque ad praesentem diem magis possum sermonem chaldeum legere et intellegere quam sonare. A comparative analysis of the Aramaic language of the Book of Tobit, attested by fragments found in the fourth cave of Qumran, dated to the second century B.C.E. with the Aramaic pericopes found in the Book of Daniel reveals many similarities.

${ }^{21}$ Jerome calls Origen Adamantius, that is, a man with steel insides (Ep. 33. 4: Videlicet, ut ad Adamantium nostrum nostrumque Chalcenterum veniamus, qui tanto studio in sanctarum Scripturarum commentariis sudore laboravit, ut iuste Adamantis nomen acceperit, Ep. 34. 1; 43. 1).

${ }^{22}$ See Hieron. Ep. 84. 6, cf. Rufinus, Apol. c. Hieron. 2. 7.

${ }^{23}$ See e. g., Hieron. In Abdiam 1. 21: Haec ad duas lucubratiunculas veterum auctoritatem secutus, et maxime expositionem Hebraicam propero sermone dictavi, aperuique os meum, sed nescio an illud Christus impleverit. Unde sapiens lector sensuum magis debet consequentiam quaerere quam eloquii venustatem. Neque enim ea lenitate, et compositione verborum dictamus, ut scribimus. Aliud est, mi Pammachi, saepe stilum vertere, et quae memoria digna sunt scribere, aliud notariorum articulis praeparatis, pudore reticendi, dictare quodcumque in buccam venerit. [...] Qui veriora et meliora dixerit, in illius sententiam transgredere, In Ag- 
In light of the abovementioned discrepancies and distortions, it is difficult to acknowledge St. Jerome's own testimonies concerning his command of Hebrew as reliable sources. We have, however, other testimonies by his contemporaries who view him as a Hebrew translator of the Old Testament and an expert on this language. One of them was Augustin of Hippo, who was initially very sceptical about the translation from the 'Hebrew truth', but eventually received Jerome's rendition with approval. The bishop of Hippo acknowledges the Vulgate's father as a Hebrew-fluent scholar. ${ }^{24}$ However, if we reflect on the validity of such assertions, Augustin's testimony lacks a strong foundation. The author of Confessions could not have verified Jerome's language proficiency because he simply did not know Hebrew. ${ }^{25}$ Augustin's judgement on the Stridon-born scholar could have only been based on opinio communis and it was spread mostly by the Monk of Bethlehem himself. ${ }^{26}$

St. Isidore of Seville repeated, in his Etymologies ${ }^{27}$, the bishop of Hippo's high opinion about St. Jerome's linguistic fluency. Due to the wide popularity of Isidore's encyclopae$\mathrm{dia},{ }^{28}$ one conviction concerning the Monk of Bethlehem clearly arose in western culture: the Stridon-born scholar was well-versed in Hebrew and was able to translate the Old Testament from that very language into Latin. ${ }^{29}$ The same opinion about the scholar was shared by Erasmus of Rotterdam who prepared many of Jerome's works for print. ${ }^{30}$ And so, for instance, while commenting on a passage from Isa (28:11), the Dutch humanist clearly affirms that St. Jerome translated this excerpt from Hebrew ${ }^{31}$. This belief existed in the collective awareness up until the end of the $17^{\text {th }}$ century.

It is difficult to delve into and verify the question of St. Jerome's knowledge of the Hebrew language and his ex Hebraica veritate translation if we only base our judgement on the testimonies of the scholar himself and of his contemporaries, as well as on the centuries-old tradition. It seems legitimate, therefore, that to determine the Vulgate's father's standard of Hebrew, we should treat his very translation of the Old Testament as the main piece of evidence. As a result, an in-depth analysis of the Hebrew Bible's Latin rendition, and a juxtaposition of this translation with Jerome's other works (mainly his exegetical

gaeum 2. 20-23: Obsecro te, lector, ut ignoscas celeri sermone dictanti, nec requiras eloquii venustatem, quam multo tempore Hebraeae linguae studio perdidi.

${ }^{24}$ See August. C. Iulianum: Nec sanctum Hieronymum, quia presbyter fuit, contemnendum arbitreris, qui graeco et latino, insuper et hebraeo, eruditus eloquio, ex occidentali ad orientalem transiens Ecclesiam, in locis sanctis atque in Litteris sacris, usque ad decrepitam vixit aetatem, De civ. D. 18. 48: [Hieronymus] homo doctissimus et omnium trium linguarum peritus.

${ }^{25}$ In any event, despite his lack of knowledge of Hebrew, Augustine himself does not refrain from referring to the nuances hidden in the Hebrew text of the Book of Numbers 32:1-2 in his exegetical arguments. He can do so because he uses comments from his predecessors. See August., Locutiones in Numeros 110: Non est ista vel graeca vel latina locutio: 'dixerunt dicentes', sed hebraea videtur.

${ }^{26}$ Hieron. C. Rufinum 2. 22: Ergo et apostolus et apostolici viri, qui linguis loquebantur, in crimine sunt, et me trilinguem bilinguis ipse ridebis? Cf. Ep. adv. Rufinum 6.

27 Isid. Etym. 7. 1. 1: Beatissimus Hieronymus, vir eruditissimus et multarum linguarum peritus, Hebraeorum nominum interpretationem primus in Latinam linguam convertit. Cf. Cassiodorus Expositio psalmorum 11: Hieronymus, hebraicae linguae doctissimus inquisitor.

28 More than 1,000 manuscripts of this work have been preserved. See Van den Abeele 2008, 199-201.

29 Cf. Vincentius Belvacensis Speculum doctrinale 17. 40. 1577: Presbyter quoque Hieronymus, trium linguarum peritus, de Hebraeo in Latinum eloquium easdem scripturas convertit, eloquenter que transfudit.

30 Cf. Erasmus Ep. 273. 14-17.

31 Cf. Erasmus, In Epistolam ad Corinthios Priorem Annotationes 14. 21 (van Poll-van de Lisdonk, 2003, 278): Locus quem adducit, est apud Esaiam capite vigesimo octavo: 'In loquela enim labii et in lingua altera loquetur ad populum istum, cui dixit'. Sic enim Hieronymus reddidit Hebraica. 
pieces), seem to be the most reliable ways of gaining insight into the problem of Jerome's interpretation and his command of Hebrew.

For the first time the axiom of the Hebraist Jerome had been tarnished in 1706 A.D. when Bernard de Montfaucon questioned the very existence of the scholar's Jewish teachers. The Benedictine publisher of the Commentary on the Book of Isaiah by Eusebius of Caesarea writes about the Vulgate's father: "Et, quod observes velim, ubicunque Eusebius se ab Hebraeo doctore, vel ab Hebraeis aliquid edidicisse ait, ibidem Hieronymus se idipsum ab Hebraeo doctore accepisse testificatur." ${ }^{32}$ A good many studies and research papers questioning (to various extents) the scholar's command of Hebrew have appeared since that moment. Some of the authors challenge that matter rather radically, such as, for instance, Pierre Nautin who bluntly asserts that St. Jerome had no knowledge of Hebrew whatsoever: "Allerdings läßt es sich beweisen, dass er diese Sprache praktisch kaum kannte. Wenn immer er in seinen Kommentaren oder anderen Werken den transkribierten hebräischen Text zitiert - und das tut er oft - oder Anmerkungen zur hebräischen Sprache macht, verdankt er die jeweilige Information seinen Quellen (Origenes, Eusebius, vielleicht auch Acacius v. Caesarea); sobald er sich jedoch von den Quellen entfernt, ist alles reine Erfindung." 33

These days opinions are divided..$^{34}$ Some researchers doubt Jerome's fluency in biblical Hebrew, ${ }^{35}$ or even the existence of his Hebrew tutors, regarding it all as a hyperbole or confabulation. ${ }^{36}$ The fact that the existence of Bar-Anina and other Jews - whose accounts St. Jerome often refers to - is doubtful results from the coincidence of their explanations with those given by other Jews, whose opinions are communicated in the works by Origen and by Eusebius of Caesarea. The Monk of Bethlehem, in turn, drew liberally from their exegetical pieces - which we will discuss further on. In a letter from Constantinople, written already at the turn of 380/381 to Damasus, Jerome provides an ample explanation on the Book of Isaiah (6:8-9) that is supposed to come from a Jew he knew (Ep. 18A. 15: Hebraei mei disputationem). ${ }^{37}$ The whole account derives, however, from The Homilies on Isaiah by Origen. These were nota bene translated into Latin by the Vulgate's father around 10 years later. Origen himself had heard from 'a certain Hebrew' a similar explanation to the one given by the Stridon-born scholar. The information about Isaiah's vision against Jerusalem (Isa 22) - which Jerome quotes in his Commentary on Isaiah, and which, according to him, he had been told by a Hebrew (referebat mihi Hebraeus) - is identical to the information Eusebius cites in his commentary on the same prophet. The

32 de Montfaucon. Praef. in Comm. in Hesaiam Eusebii Pamphili 4.3 (PG 24, 88).

33 Nautin 1986, 309.

34 Researchers who support a good command of Hebrew by St. Hieronim and those who doubt it to a varying degree are listed by Michael Graves $(2007,1-9)$. To this day, there are many scholars who still repeat the opinion of St. Isidore of Seville. See e. g., Krumeich, 1993, 16-17. Interestingly, it is noticeable that scholars who doubt the Jerome-Hebrew axiom study mainly Greek Christian authors.

35 There are, however, also researchers who do not doubt that Jerome's command of biblical Hebrew was quite fluent. Raúl González Salinero, for instance, states that Jerome’s level of studies on biblical philology was higher than Origen's: "Si la 'graeca veritas' había triunfado durante su época romana, su estancia en Belén y su acercamiento a las 'Hexaplas' terminaron por inclinar su trabajo hacia la a 'hebraica veritas', el último y más perfecto nivel en el estudio filológico y exegético de la Biblia, muy superior a la «simple» labor crítica emprendida por Orígenes" $(2003,39)$.

36 Froehlich 2014, 30-32.

37 Hieron. Ep. 18A. 15. 
Caesarea's bishop also claims that he had heard such an account from some Jew. ${ }^{38}$ Gustave Bardy (1881-1955), a professor in the Institut Catholique de Lille specialising in the Greek patristics, enumerates more places in St. Jerome's texts where the scholar refers to the information allegedly heard from his Hebrew source, and which de facto comes from Origen and Eusebius's writings. ${ }^{39}$ Those two authors also mention that some of their sources of information were unknown to 'us Jews. ${ }^{40}$ Jerome himself admits that both of those Greek writers recount the rabbinic exegesis in this very way:

Ipse Origenes et Eusebius et Clemens alii que conplures, quando de Scripturis aliqua disputant, et volunt approbare quod dicunt, sic solent scribere: 'Referebat mihi Hebraeus'; et: 'audivi ab Hebraeo'; et: 'Hebraeorum ista sententia est'.

"Origen himself, Clement, Eusebius and many others, when they discuss the Scripture and want to justify their opinions, they usually write: 'a Hebrew conveyed me'; 'I heard from a Hebrew'; 'this is an opinion of the Hebrews."'41

Additionally, we know without fail that while writing his biblical commentaries, Jerome benefited greatly from the academic achievement and heritage of the Greek exegesis of Alexandria. Around 393 A. D. in his foreword to the second book of the Commentary on Micah, the Vulgate's father refutes the accusations posed by his adversaries as to the authenticity of his exegesis. Jerome tries to silence his critics, comparing them to barking dogs and Hydra's heads that could be crushed, but only for a short time because they grow back straightaway. The scholar concludes that there is no shame in drawing from the works of Greek exegetists. ${ }^{42}$ This short apologia, backed with examples from classical literature, exposes the fact that St. Jerome, when writing his commentaries, drew from Origen and other scholars from the Catechetical School of Alexandria while leaving it unsaid. In the prologue to his Commentary on Matthew, addressed to Eusebius of Cremona, Jerome 'plays it safe' again, insuring himself against any possible mistakes he had made and blaming the quick pace of dictating this piece. He asks his addressee - although Eusebius might think that he is rather reading a text by some strange authors and not by Jerome himself - to forgive him any stylistic lapses and mistakes, and to be indulgent ${ }^{43}$ with him. The Stridon-born scholar was well aware that the monk from Cremona was well-read in Greek exegesis and that he might notice that the commentary he got from Jerome was not the scholar's authorial work. ${ }^{44} \mathrm{~A}$ comparative reading of St. Jerome's Commentary on Zechariah (written between 406-407 A. D.) and the commentary on the same prophet by Didymus the Blind reveals that the Monk of Bethlehem blindly rewrote the whole pericopes from the Origen's student's work, including the errors. ${ }^{45}$ For instance, he

38 See. Hieron. In Esaiam 5. 22. 1b; 5. 22. 15/25 and cf. Euseb. In Esaiam 82 (22. 15-25).

39 See Bardy 1934, 148-164.

40 See e. g., Nautin 1977, 214-219; 284-292; 326-361.

${ }^{41}$ Hieron. C. Rufinum 1. 13.

42 Hieron. In Michaeam 2. prol.: Nam quod dicunt, Origenis me volumina compilare, et contaminari non decere veterum scripta, quod illi maledictum vehemens esse existimant, eandem laudem ego maximam duco, cum illum imitari volo, quem cunctis prudentibus, et vobis placere non dubito.

${ }^{43}$ Hieron. In Matthaeum 1. prol.: Certe nosti, et mendacii mei erubescerem te testem vocare, quod praesens opusculum tanta celeritate dictaverim ut magis aliena legere quam mea condere me putares.

${ }^{44}$ Jerome's Commentary on Matthew is heavily dependent on its Greek sources. Cf. Scheck 2008, 19-23.

45 Cf. e. g., Didymus In Zachariam 2. 126 and Hieron. In Zachariam 2. 7. 8/14, where Jerome quotes after Didymus a passage which he considers to be Jeremiah's, but in fact it is not in Jeremiah. 
took the interpretation of Zech 14:3-4 entirely from Didymus. ${ }^{46}$ It does not trouble Jerome to attribute the exposition of this periscope to himself:

Haec ut in locis difficillimis et valde obscuris, pro tenuitate virium nostrarum diximus.

"Since those passages are very difficult and obscure, we rendered them as good as our capabilities allowed us." 47

There is no doubt that Jerome's exegesis, though consistent with the hermeneutical tradition of the era, is highly dependent on biblical commentaries by the Greek fathers. As to the Old Testament rendition, it turns out that even Jerome's decisions in regard to interpretations - although they seem to be made on his own - come from the Greek translators. For instance, while translating the Book of Zechariah 5:9, he wrote that the women the prophet saw had wings like a falcon's (milvus). In his Commentary on Zechariah, however, he said that hexaplar translators, i.e., Aquila or Symmachus, as well as the review of the Septuagint by Theodotion, interpret the Hebrew word on). The LXX uses the name ع̈ло廿 (hoopoe) and he himself chooses milvus (falcon). ${ }^{48}$ Therefore Jerome, in a seemingly independent way, rejects the interpretations of Greek translators and follows his own idea with the identification of the problematic bird from the biblical Hebrew. But was it a conscious interpretative choice? Independent of Greek translators? It turns out that the Vulgate's father in his other work writes that the same Hebrew name, appearing in Psalm 103, was translated by Symmachus with the Greek

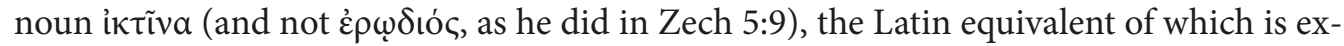
actly milvus. ${ }^{49}$ This example shows us that Jerome's sporadic own interpretive choices might be only seemingly authorial and might not at all be independent of the Greek translations.

We should ask, therefore, if St. Jerome's level of Hebrew could allow him to translate the Old Testament from this very language autonomously. Or was he forced to depend on his 'aids', i.e., the hexaplar Greek renditions, and that means de facto translating/ interpreting decisions of Aquila, Symmachus and Theodotion? Therefore, the question is: was Jerome in control of his translation, taking 'Hebrew truth' as a source and final judgement? Or did his rendition drift away from it towards the hexaplar Greek interpretations - which would actually become the basis of the scholar's translation? If the Vulgate's father had not relied directly on the Hebrew text while translating, then we can say that the original Hebrew Bible ceased to be the foundation of this rendition. Instead, the Greek translation and its interpretations became Jerome's bases. While assessing the Monk of Bethlehem as a translator from Hebrew, we must take this factor as decisive: the scholar may, of course, make use of various Greek interpretations or dictionaries. However, if we accept the fact that he did his translation from Hebrew, as he emphasised many times, and that he did so only occasionally leaning on his Jewish teachers' guidelines, we must conclude that, in the end, he should have based his rendition on the Hebrew text and the original Hebrew version should have been crucial to him. Of course, errors can occur and the translator can misread the original word, e. g., mistake the Hebrew letter dalet with

${ }^{46}$ Cf. Didymus In Zachariam 5. 365-366 and Hieron. In Zachariam 3. 14. 3/4.

47 Hieron. In Zachariam 3. 14. 3/4.

48 Hieron. In Zachariam 1. 5. 9-11.

49 Hieron. Ep. 106. 65. 
$\operatorname{resh}^{50}$ and, because of that, change the original meaning. He can also, drawing on his $l i-$ centia poetica, walk away from the literal meaning of a phrase, and, for instance, introduce an idiomatic, figurative or symbolic meaning - but he must do so on the basis of and being in control of the original text. But if the translator makes use of some other-language renditions of the original, he cannot incorporate any changes of the meanings, based only on those interpretations and without the final consultation with the text in its original language. If the original text is corrupted or unintelligible, it seems acceptable to draw from its interpretations. Meanwhile Jerome, in his translating praxis ex Hebraica veritate, does not often confront or consult his interpretations with the original, and mostly relies on the hexaplar renditions by Symmachus or Aquila - which can be proven by his numerous interpreting choices in more 'difficult' passages. ${ }^{51}$ And so, if St. Jerome constantly refers to either Symmachus or Aquila, he does not translate from Hebrew but from Greek.

The aim of this article is to again voice an opinion on the matter of Jerome's command of Hebrew and of the usage of those skills in his translation of the Old Testament. We would like to make an attempt at assessing how much of the scholar's level of Hebrew allowed him to make autonomous and arbitrary decisions on his interpretative choices based on the original text - while he worked on the translation of the Holy Scripture. We will reflect on whether the Vulgate's father is true to his abovementioned main premises: is he the conveyor of a new interpretation of the Hebrew Bible? Is he an active, direct translator from the original language? We will aim to express our opinion on that matter by presenting here one specific verse from the Book of Deuteronomy.

The date of the translation of the Book of Deuteronomy by St. Jerome is uncertain. The scholar rendered the Pentateuch into Latin somewhere between 398 and 404/405 A.D. ${ }^{52}$ In his letter 71 from 398 A. D., he writes to Lucinius of Baetica:

Canonem Hebraicae veritatis, excepto Octateucho, quem nunc in manibus habeo, pueris tuis et notariis describendum dedi.

"I gave the 'Canon Hebraicae Veritatis', except for the Octateuch, to your slaves and secretaries so that they rewrite it." 53

This would mean that Jerome started his work on the Octateuch exactly then, in 398 A. D. In his Apology against Rufinus, dated at the turn of the $4^{\text {th }}$ and $5^{\text {th }}$ century, the

50 Cf. Hieron. In Esaiam 5. 21. 11-12.

51 It is significant that he often chooses a lesson from the Greek translation, despite the importance of the sense of the Hebrew original. As, for example, in Deut. 9:9, he takes the meaning from Symmachus, which is noted and commented on by Sebastian Weigert, the author of the recently published monograph on Jerome's translation of the Book of Deuteronomy $(2016,130)$ : “Der masoretische Text liest hier (und

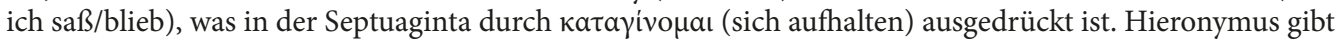
hier wohl die Symmachus-Fassung $\pi \alpha \rho \varepsilon \dot{\mu} \varepsilon \varepsilon v a$ durch perseveravi (verharren) wieder. Auffällig daran ist, dass auch die Septuaginta einen Text bietet, der den hebräischen verständlich wiedergibt. Dennoch schließt sich Hieronymus der Interpretation von Symmachus an." Cf. Salvesen 1991, 276.

52 Such a date for the origin of the Pentateuch was given at first by Samuel Berger $(1902,19)$. Cf. Kelly 1975, 283-284 and Brown Tkacz 1996, 51: "Thus, by the end of 398, of the Hebrew books only the Octateuch remained to translate, and he was working on it. The Octateuch consists of the Pentateuch-namely, the five books attributed to Moses: Genesis, Exodus, Leviticus, Numbers, and Deuteronomy-with Joshua, the pair of Judges and Ruth counted as one book, and Esther. He finished work on the Octateuch by 404/5, thus completing his translation of the Hebrew canon."

53 Hieron., Ep. 71. 5. 
Monk of Bethlehem writes, in turn, that he had translated the Pentateuch from Hebrew. ${ }^{54}$ And this would mean, then, that when he was writing the polemic piece, his work on the Pentateuch had already been completed. As we are uncertain as to when the Apology $y^{55}$ was actually created, we could cautiously assume that the translation of the Book of Deuterono$m y$ had, at the latest, been finished in 404/405 A. D. ${ }^{56}$ Taking into consideration such a late terminus ante quem and terminus post quem of the work on this rendition, we could claim that Jerome was an already skilful translator at that time. He was working on this biblical book carrying quite a baggage of interpreting experiences: he had already translated the Books of Samuel and Kings (390), Psalterium iuxta Hebraeos, all of the prophetic books and Job (392/393), Ezra, Nehemiah and the Books of Chronicles (396), Proverbs, Qoheleth, and the Song of Songs (autumn of 398 - during only three days!).

The verse of our interest is, as we have already mentioned, in the Book of Deuteronomy. It is in a passage dedicated to the protective strength of God, which he showed to his people after they had left Egypt. In verse 8:15 we have mention of the dangers of the desert, which was translated by Jerome thus:

et ductor tuus fuit in solitudine magna atque terribili in qua erat serpens flatu adurens et scorpio ac dipsas et nullae omnino aquae qui eduxit rivos de petra durissima.

"I was your guide in the vast and terrible desert, where there was the serpent with its burning breath and the scorpion and the dipsas snake and there was no water, (I was the one) who brought out a stream from the hardest rock."

Among many genera and species of snakes or vipers found in Jerome's Latin translation of the Bible (aspis, coluber, vipera, serpens, basiliscus/regulus), the second venomous snake mentioned here, defined by the ancient Greeks and Romans as dipsas ${ }^{57}$ (or in the Latinised form situla) appears in the Holy Scripture only once, precisely in the verse from Deuteronomy quoted above. The appearance of this very snake in St. Jerome's translation sheds some light on the interpreting matters connected with the Stridon-born scholar's rendition ex Hebraica veritate. If we refer to the 'Hebrew truth,' we will notice some differences concerning the content and the meaning of this verse:

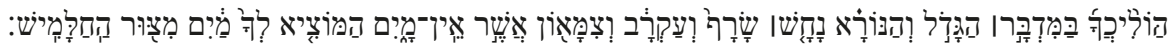

"I was leading you through the great and terrible desert of the venomous snake and the scorpion and the arid land which has no water, I was deriving water for you from the hard rock."

The biblical author depicts, therefore, a slightly different image of the desert and its dangers, where the Israelites were threatened by two poisonous creatures - the snake and the scorpion - on the one hand, and the dry land and lack of water on the other.

In Jerome's version not two but three venomous animals are lying in wait for the Israelites. We have the serpent burning with its breath, the scorpion and the dipsas. The translator also, in comparison to the Hebrew version, changed the way in which he writes about those dangers, listing them sequentially and linking them with et or $a c$. Thus, the

${ }^{54}$ Hieron. C. Rufinum 2. 25.

55 Perhaps this work was written around 400-401. Cf. Kelly 1975, 254.

56 Sebastian Weigert (2016) himself is quite ambiguous on the estimation of the date for the translation of Deut: he once states that it is ca. 403 (p. 38, note 122), once ca. 400 (p. 39).

57 This snake is now identified by scientists as Cerastes vipera or Pseudocerastes persicus (Leitz 1997, 94). 
lack of water was added as the fourth danger during the migration through the desert, right after the venomous fauna.

By comparing St. Jerome's version to the Hebrew original, we may notice that the scholar's translation is a more powerful and dramatic description due to the expanded information about the deadly desert beasts. Their larger number and their extraordinary abilities (flatu adurens burning with breath from a distance ${ }^{58}$ ) make the description more sinister and frightening than in the Hebrew text.

Thanks to this interpretation, the poignancy of Jerome's version is significantly enhanced. And the appearance of an additional snake, a dipsas, ${ }^{59}$ and its specific, lethal features further heightens the image of terror. Let us have a look at an exceptionally vivid depiction of the dipsas venom's effects given in Pharsalia $9.738-760$ by Lucan:

signiferum iuuenem Tyrrheni sanguinis Aulum
torta caput retro dipsas calcata momordit.
uix dolor aut sensus dentis fuit, ipsaque leti
frons caret inuidia nec quicquam plaga minatur.
ecce, subit uirus tacitum, carpitque medullas
ignis edax calidaque incendit uiscera tabe.
ebibit umorem circum uitalia fusum
pestis et in sicco linguam torrere palato
coepit; defessos iret qui sudor in artus
non fuit, atque oculos lacrimarum uena refugit.
non decus imperii, non maesti iura Catonis
ardentem tenuere uirum, ne spargere signa
auderet totisque furens exquireret aruis
quas poscebat aquas sitiens in corde uenenum.
ille uel in Tanain missus Rhodanumque Padumque
arderet Nilumque bibens per rura uagantem.
accessit morti Libye, fatique minorem
famam dipsas habet terris adiuta perustis.
scrutatur uenas penitus squalentis harenae,
nunc redit ad Syrtes et fluctus accipit ore,
aequoreusque placet, sed non et sufficit, umor.
nec sentit fatique genus mortemque ueneni,
sed putat esse sitim; ferroque aperire tumentis
sustinuit uenas atque os inplere cruore.

"So Aulus, a standard-bearer of Etruscan blood, trod on a dipsas, and it drew back its head and bit him. He had hardly any pain or feeling of the bite; the mere appearance of the deadly wound was innocent, nor did the injury threaten any consequences. But lo! the hidden venom rises; devouring flame catches hold of the marrow and kindles the inmost parts with destroying fire. The poison dried up the moisture that surrounds the vital organs, and began to consume the tongue in the parched mouth ; no sweat was left to run down over the suffering limbs, and the flow of tears deserted the eyes. The man was on fire ; and neither na-

${ }^{58}$ It is significant that the LXX interprets and translates this Hebrew term for serpent in a way that is devoid of sensationalism, as simply a 'biting snake' (ö

59 The dipsas snake appears earliest in the ancient literature in Nicander of Colophon in his Of Venomous Animals (Ther. 334n). 
tional pride nor the authority of grief-stricken Cato could stop him : boldly he threw down the standard and searched everywhere in his frenzy for the water which the thirsty poison at his heart demanded. If he were plunged into the Tanais, the Rhone, or the Po, he would go on burning, or if he drank of the Nile when it floods the fields. But Libya made death more deadly; and the dipsas, when aided by the heat of that country, deserves less fame for its powers of destruction. Aulus searches for water deep down in the barren sand, and then returns to the Syrtes, and swallows the brine ; the sea-water gives him pleasure, but there is not enough of it. The nature of his suffering and his death by poison were unperceived by him: he thought it was merely thirst, and ventured to open his swollen veins with his sword, and fill his mouth with the blood." 60

We quote Lucan, though dipsas had been mentioned by other Roman poets and writers ${ }^{61}$ since it is highly probable that Jerome had come to know this poetic description already in his school years when Pharsalia was read, analysed and discussed. ${ }^{62}$ Jerome frequently mentions quotations and phrases from Lucan in his writings. ${ }^{63} \mathrm{He}$ could also have heard about the dipsas snake later on, while reading the texts by Greek ecclesiastical authors (works he also drew from). ${ }^{64}$

In this manner, St. Jerome's version of verse Deut. 8:15 places a stronger emphasis on the terrifying danger lurking in the desert. He depicts an exceptionally ominous image of the desert through references to the dangers threatening the Israelites. In Jerome's writing, they are not only the venomous beasts we read of in the Hebrew original or in the Septuagint translation. They are the creatures with extraordinary, deadly features, the terrifying, fire-breathing serpents, ${ }^{65}$ the scorpions, and finally the dipsades inducing unquenchable thirst. Moreover, the aspect of the lack of water is particularly emphasised and intensified

60 Transl. Duff 1928, 561.

${ }^{61}$ However, not always with such dramatic and colourful bluntness as the author of Pharsalia. For example, Sil. Pun. 3. 313; Mart. Epigr. 3. 44. 7-8 (interestingly, Martial mentions this snake in comparison with scorpions: Non dipsas medio perusta sole, / Nec sic scorpios inprobus timetur); Celsus Med. 5. 27. 7; Plin. HN 23. 152, 32. 46; Solin. 27. 31; Amm. Marc. 22. 15. 27. Sallust perhaps also mentions a dipsas snake (Iug. 89. 5). See Gilbert 1975, 68.

62 See Hagendahl 1958, 284. Jerome writes about the comments he read on Lucan among the comments to other school authors: Puto quod puer legeris Aspri in Vergilium ac Sallustium commentarios, Vulcatii in orationes Ciceronis, Victorini in dialogos eius, et in Terentii comoedia praeceptoris mei Donati, aeque in Vergilium, et aliorum in alios, Plautum videlicet, Lucretium, Flaccum, Persium atque Lucanum (C. Rufinum 1. 16).

${ }^{63}$ It uses Pharsalia as a source of knowledge as well as accurate sayings. E. g., Ep. 58. 7: et nomina vana Catonum (cf. Phars. 1.313), Ep. 123. 17: Potentiam Romanae urbis ardens poeta describens ait: 'Quid satis est, si Roma parum est'? (cf. Phars. 5. 274), In Esaiam 18. 66. 18/19: de quibus pulchre Lucanus: 'Gallorum Celtae miscentes nomen Hiberis' (cf. Phars. 4. 10).

64 E. g., Gregory of Nazianzus - about whom Jerome himself writes: Gregorius, Nazianzenus episcopus, vir eloquentissimus, praeceptor meus et quo Scripturas explanante didici (De vir. ill. 117, cf. Hieron. Ep. 52.

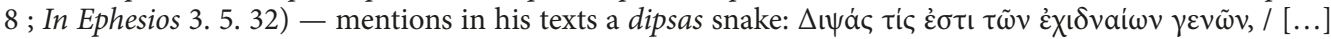

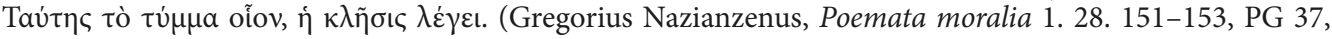
$867)$. In the years $379-382$, St. Jerome stayed in Constantinople where he listened to Gregory's of Nazianzus catecheses.

${ }^{65}$ By this kind of expression, the snake could be associated with the description of a basilisk, which destroyed the surroundings not only by touch, but even by breathing, burning the vegetation (Plin. HN 8. 76: necat frutices, non contactos modo, verum et adflatos, exurit herbas). Basilisk by name appears very often in Jerome's translation of the OT: Isa 8:17, 11:8, 14:29, 30:6 (regulus volans), 59:5, Prov 23:32, Ps 90:13 (basiliscus) as well as in his other writings, e. g. Vita Malchi 9: Igitur timentes venenata animalia (solent quippe viperae, reguli et scorpiones cetera que huiuscemodi, fervorem solis declinantia, umbras petere) intramus quidem speluncam. 
here. The information nullae omnino aquae, which appears directly after the dipsas, is a merciless predictor of additional horrific suffering to come from thirst in the event of being bitten and a cruel imminent death.

Introducing a dipsas, non-existent in the Hebrew original, led to its subsequent reception in literature. We could say that the dipsas was seriously treated as one of the serpents harassing the Jews on their journey through the desert. Sanctioned by the authority of the Latin Bible, it started to appear in mediaeval encyclopaedias and commentaries. ${ }^{66}$

Here, however, we should pose a question: is this version by Jerome a product of a well-thought-out interpretation and a deliberate exaggeration of the dangers? There is every indication we should reject such an explanation. All the more so because the scholar's rendition oversteps the boundaries of even the ad sensum translation. ${ }^{67}$ Jerome, introducing the equivalent of dipsas in lieu of the Hebrew term צִ צִ (dry land, parched ground), conveys neither the nature nor the features of the Hebrew counterpart. We can observe that, for instance, in the Septuagint in Deut. 14:5 kosher wild-horned (or antlered) Palestinian animals were replaced with African ones, or one demonic creature from the realm of Semitic imagery/mythology was substituted with one more recognisable in the Graeco-Roman world. ${ }^{68}$ Yet in the case of Deut. 8:15, we find an unusual interpretive 'trick' in the shape of introducing a venomous snake species in lieu of a Hebrew name referring to land features, or environmental conditions. It is therefore a rather significant change made by a leap from inanimate nature to an equivalent of animate nature.

So, what was Jerome led by in his identification with a snake? Could he have mistaken the name for a dry land with a similar word in Hebrew that described a viper or a snake? Out of all the Hebrew names for those reptiles, the only word with any semblance could be צִפְפנִני (e. g., Prov. 23:32), meaning 'viper'. But even those words are distinct enough that

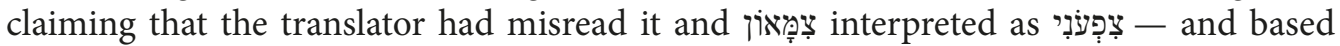
on that he introduced an additional snake - should hardly be perceived as convincing, or rather unlikely. It is even less probable as, directly after this term, we can find in the Hebrew text a relative pronoun wִ introducing a relative clause added to צִּ which would be quite bizarre and nonsensical in reference to any kind of snake: 'the snake which has no water.'

Additionally, the word 8:15, Ps. 107:33, Isa 35:7) in all of the ancient renditions and interpretations is describing

66 See Isid. Etym. 12. 4. 13; 12. 4. 32. We find interesting information in the 13th-century encyclopaedia of Thomas of Cantimpré, where we can read about three types of serpents that threatened the Israelites during their wandering through the desert, including the dipsas snake, Liber de natura rerum 8. 16. 14 : Contra tria genera serpentium, ut dicit Iacobus, qui filios Israal in deserto vexaverunt, erectus est serpens eneus ex precepto Domini in palo per Moysen latorem legis. Hos fuisse dicunt: dypsades, sytulas et scorpiones (as we can see from the example of scorpions, the systematics of the ancients differs from modern findings). See Appendix, illustrations 1-3.

67 See Hieron. Ep. 57.5 (A. D. 395/396): Ego enim non solum fateor, sed libera voce profiteor, me in interpretatione Graecorum, absque Scripturis sanctis, ubi et verborum ordo mysterium est, non verbum e verbo, sed sensum exprimere de sensu. Years later, Jerome has a similar opinion on this matter: Librum Hesther (...) quem ego de archivis Hebraeorum relevans, verbum e verbo pressius transtuli (Praef. in Hesther, A. D. 405-407).

68 This cultural translation is mentioned by Jerome himself, pointing out that already in Greek translations of the OT the translators did not literally reflect the Hebrew realities, but replaced them with terms better associated with the Greek world: Nomen autem gigantum, pro quo in hebraeo GEBBORIM, id est fortium, positum est, LXX et Theodotio in similitudinem fabularum vertere gentilium, sicut et Sirenas et Titanas et Arcturum et Hyadas et Orionem nominant, quae apud Hebraeos aliis appellantur vocabulis (Hieron. In Esaiam 6. 13. 3). 
a waterless land, and we will not find even the slightest hint that it might be some representative of desert fauna. Jerome himself translates this word as "dry land" in the two other abovementioned instances. In Isa 35:7 we can read about changing dry lands into watered ones:

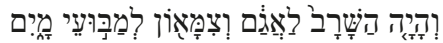

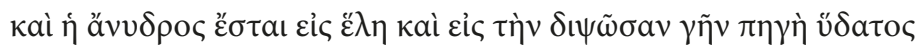

et quae erat arida in stagnum et sitiens in fontes aquarum

"And which (land) was dry (became) a swamp and the thirsty the springs of water."

Cf. Ps. 107:33 - a reverse situation, where a land abundant in water becomes a waterless desert:

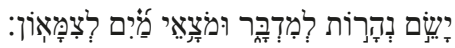

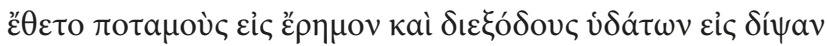

posuit flumina in desertum et exitus aquarum in sitim

"(God) changed the rivers into a desert, oases into the thirsty land."

Thus, it is not an error in translation in regard to the Hebrew language. Was then the Hebraica veritas the foundation and source of reference for Jerome's translation? Or was it really some other text?

Dipsas as a term describing a venomous snake came into Latin from Greek where it is related to the noun $\delta$ í $\psi \alpha$, meaning thirst or a dry land. ${ }^{69}$ As we have already mentioned, in St. Jerome's translation an arid land had been mistaken for a venomous snake. In the Hebrew language as well as in Latin such a textual error could not have occurred. In Latin, a dry land was called by the native sitis (hence the Latinised form of the dipsas snake: situla $^{70}$ ). Therefore, it is highly likely that in Old Latin renditions of the Bible in the LXX,

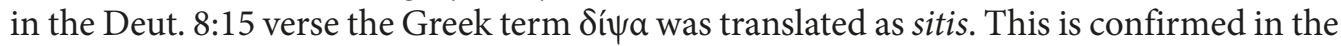
Vetus Latina Hispana. ${ }^{71}$

The possibility of such a textual error or misunderstanding exists only in the realm of the Greek language, where we actually have two similar forms for two different terms:

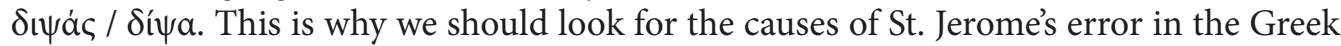
translations of the Old Testament, although even in this matter some scholars have voiced their reservations. For instance, Samuel Bochart, a leading seventeenth-century French Biblicist, while reflecting on the dipsas introduced to the Bible - and this exists only in Jerome's translation ("neque enim eorum ullus est, qui dipsadem hic intelligat, aut aliud serpentis genus") ${ }^{72}$ - ruled out the influence of the Greek rendition. He argued that the

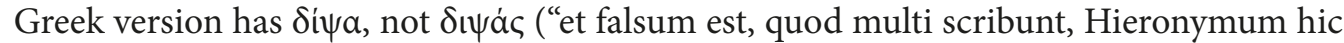

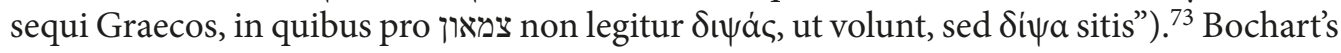

${ }^{69} \Delta ı \dot{\alpha} \varsigma$ - a zoonym coined from Sí $\psi \alpha$ due to the effects the bite of this snake causes. See Beekes 2010,342 . siti perit.

${ }^{70}$ Cf. e. g., Isid. Etym. 12. 4. 13: Dipsas, genus aspidis, qui Latine situla dicitur, quia quem momorderit

${ }^{71}$ See Ayuso Marazuela 1967, 252.

72 Bochart 1712, 398.

73 Bochart 1712, 398. 
reservations do not, however, constitute a strong argument, especially since we cannot rule out the possibility that St. Jerome made use of a LXX manuscript where a scribe's textual mistake in the form of $\delta ı \psi \alpha$ a might have occurred. ${ }^{74}$ What is more, such Greek terms misread by Jerome himself are not uncommon. Another example we can give is $\tau \tilde{\omega} v$ $\varphi \omega \dot{v} \omega \nu$ misread as $\tau v \varphi \omega ́ v \omega v^{75}$ - from Aquila's translation of the Book of Isaiah 13:21.

Jerome, working on his translation of the Bible, relied on the hexaplar renditions. In the case reviewed in this article we can assume, with a high probability, that it had been Symmachus's translation, which can be seen in the literally taken phrase

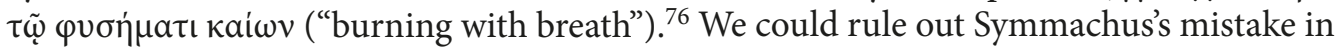
naming a waterless land by a term for a snake. It would have simply been impossible in regard to Hebrew (unless Symmachus based his translation on the Greek version). Most

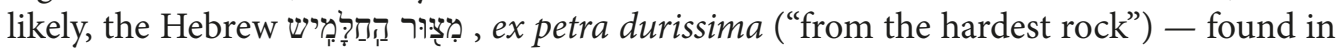
the verse analysed by us - was also taken by Jerome from Symmachus. Admittedly, there is no direct evidence or testimony telling us outright what Symmachus' interpretation of this term in Deut. 8:15 was, but we can come to this conclusion in an indirect way.

In his Commentary on Hosea Jerome writes that Symmachus, alongside Aquila and Theodotion, translates the Hebrew sor (צוּ) as petra durissima ${ }^{77}$ and that is - as we read, in turn, in the scholar's Commentary on Amos - ákpóto $\mu$ os in Greek (sed sur legendum,

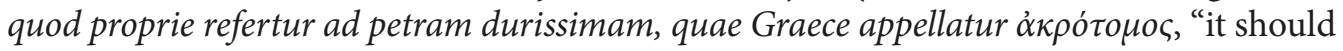
be read SUR which in a proper sense refers to the hardest rock which the Greeks called

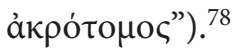

All the other Greek translations from the $2^{\text {nd }}$ century, except for LXX, had probably interpreted the Hebrew term צִ wִָָאוֹן with the most adequate Greek equivalent, and that is Síqa. The structure of the sentence in the Greek rendition was not inconsequential to St. Jerome's error in the interpretation of this term. We can only see it in the Septuagint, but it can provide us insight into what it could have looked like in Symmachus's writings. We should also note that Jerome knew the Alexandrian translators' works and that he drew on them, if required, for their identifications - for instance, where the hexaplar renditions had not translated Hebrew terms or names (compare Jerome's version of Isa

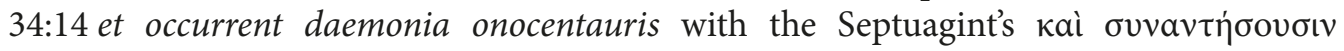

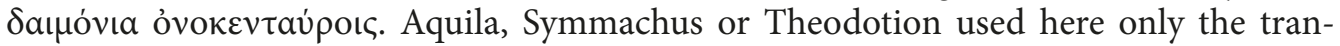
scription of the Hebrew name).

If Jerome had looked at the Hebrew version, the construction of the sentences themselves should have made him think over the sense and logic of introducing a third poisonous animal in his translation. If, however, he had read only the Greek version, he would not have had to face the dilemma of finding a logical sense in case of misreading di $\psi \alpha$ as

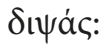

74 Cf. Weigert 2016, 130: Vielleicht liest Hieronymus in Dtn 8,15 unter dem Eindruck der beiden ander-

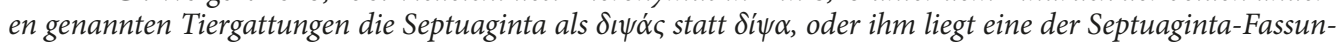

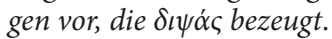

75 See Morta 2021, 138.

76 See Salvesen 1991, 150 and Weigert 2016, 129-130. Symmachus not only translated from Hebrew, but also used rabbinic commentaries, the midrashes. On the influence of the Midrash on Symmachus's ver-

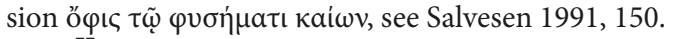

77 Hieron. In Osee 2. 9. 11/13.

78 Hieron. In Amos 1. 3. 11. 


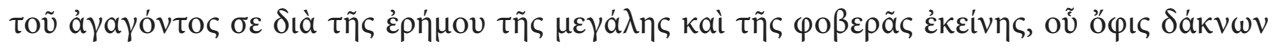

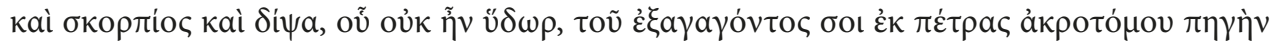

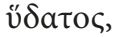

"He who had led you through the vast and terrible desert where there was the biting viper and the scorpion and parched land, where there was no water, he who brought out for you a spring of water from the hard rock."

We should notice that in the LXX version we can find the adverb ov (where) twice, which separates the three initial dangers from the fourth one. As a result, this Greek sentence can be understood in two ways. The second oṽ refers to either a dry land ( $\delta i \psi \alpha)$ or a desert ( $\tau \tilde{\eta} \varsigma \dot{\varepsilon} \rho \eta \dot{\eta} \mu v)$ - and that is how Jerome read it. The conjunction $e$ t he used before nullae omnino aquae irrefutably proves that the second oṽ was read by Jerome as being unconnected with $\delta i \psi \alpha$, but referring to the description of the vast and terrible desert ( $\tau \tilde{\eta} \varsigma$

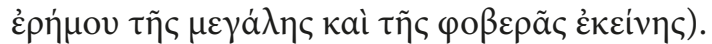

Therefore, if Jerome had been working with the Hebrew text, he would not have been able to make such a mistake with identification. Even if, for some reason, the scholar had acknowledged the identification of צִיָָאוֹן as a snake - e. g., influenced by the Greek identification found in a corrupted manuscript - the context of the Hebrew sentence should have forced him to revise this error. Otherwise, he would have had to deliberately modify the Hebrew text in order to obtain logical content and implement his own syntactic correction. ${ }^{79}$

Consequently, it is evident that the 'distortion' of verse Deut. 8:15 made by St. Jerome must have been influenced by the Greek translation (probably by Symmachus) and by two circumstances related to it:

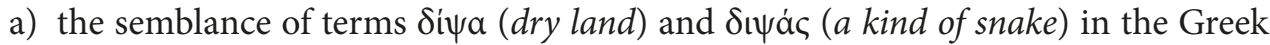
language;

b) the structure of the sentence (in this case, the ambiguous sentential construction).

There were also additional factors contributing to this mistake, for instance the Stridon-born scholar's education. Since his school years Jerome could have been familiarising himself with impressive and dramatic descriptions of dipsas while reading classical authors and commentaries on their works. Such a reading might have enhanced this suggestion. We should also take into consideration - which is also indicated by the author of the monograph on Jerome's translation of the Book of Deuteronomy, which we have already

79 Just like Samuel Bochart presents it, although in his deliberations on Jerome's error he comes to conclusions completely different from ours. In his argumentation and explanations, the French scholar tries to prove in a very unconvincing way that Jerome consciously made changes to the Hebrew text in order to save the sense of this description. He points out that after

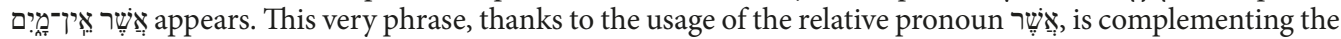

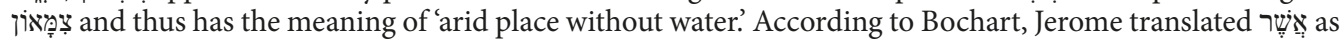
$a c$, so he slightly changed the original. As a result, he detached the dipsas from the relative clause and avoided the curious 'snake without water' in his translation (Bochart 1712, 398: Sed 'Hieronymus' illam incidit post vocem וצמיאון, quam reddidit 'ac dipsas'. Et sequentia אשר אין מים (Bd ac 'nullae omnino aquae,, vocula 'ac' de suo addita, ne referrentur ad proximum antecedens, quia nullus fuisset sensus horum verborum, 'Dipsas, in qua non sunt aquae'). However, Bochart's argument has a weak point. If we accept such an explanation of the French scholar, and since Jerome relies on the Hebrew text (even making modifications to it), then we should pose one question: why did he introduce a second snake in this sentence? A snake which, by the way, did not appear in the Hebrew text. It is clear here that Bochart by no means takes into account that Jerome may not have confronted his translation with the Hebrew original. 
cited several times, Samuel Weigert ${ }^{80}$ - that the Monk of Bethlehem might have been influenced by the two earlier mentioned desert animals.

However, we should also remember that those additional factors would have had no influence on the translation if, in this very case, Jerome had done exactly what he had claimed to do in various other instances and that is confront and consult his interpretation with the 'Hebrew truth'.

\section{References}

Adriaen M. (ed.). Magni Aurelii Cassiodorii Expositio psalmorum I-LXX. Turnholti, Brepols, 1958.

Adriaen M. (ed.). S. Hieronymi presbyteri Commentariorum in Esaiam libri I-XVIII. Corpus Christianorum. Series Latina 73 et 73A; Turnholti, Brepols, 1963.

Adriaen M. (ed.). S. Hieronymi presbyteri Commentarii in Prophetas Minores. Corpus Christianorum. Series Latina 76 et 76A; Turnholti, Brepols, 1969-1970.

Allen P.S. (ed.). Opus Epistolarum Des. Erasmi Roterodami. T. 1: 1484-1514. Oxonii, Oxford University Press, 1992 [1906].

Ayuso Marazuela T. (ed., comm.). La Vetus Latina hispana. II: El Octateuco. Madrid, El Consejo Superior de Investigaciones Científicas. Instituto Francisco Suárez, 1967.

Bardy G. Saint Jérôme et ses maîtres hébreux. Revue bénédictine 1934, 46, 145-164.

Beekes R. Etymological Dictionary of Greek. Volume 1. Leiden - Boston, Brill, 2010.

Bellère B. (ed.). Bibliotheca Mundi. Vincentii Burgundi... Duaci, Ex Officina Typographica B. Belleri, sub Circino aureo, 1624.

Berger J.-D. - Frézouls E. (ed., comm.). Ammien Marcellin. Histoires. Tome III. Paris, Les Belles Lettres, 2018.

Berger S. Les préfaces jointes aux livres de la Bible dans les manuscrits de la Vulgate: mémoire posthume: memoire posthume. Paris, Klincksieck, 1902.

Bochart S. Hierozoicon. Pars Posterior Libris VI. Lugduni, C. Boutesteyn et S. Luchtmans, 1712.

Boese H. (ed.). Thomas Cantimpratensis. Liber de natura rerum. Editio princeps secundum codices manuscriptos. Teil 1: Text, Berlin - New York, de Gruyter, 1973.

Bonnard É. (ed., comm.). Saint Jérôme. Commentaire sur s. Matthieu. T. 1: Livres I-II. Paris, Les éditions du Cerf, 1978.

Brodersen K. (ed., comm.). Solinus. Wunder der Welt. Collectanea rerum mirabilium. Lateinisch und Deutsch. Edition Antike, Darmstadt, Wiss. Buchgesellschaft, 2014.

Brown Tkacz C. 'Labor Tam Utilis': The Creation of the Vulgate. Vigiliae Christianae 1996, 50 (1), 42-72.

Devallet G., Miniconi P. (eds, comm.). Silius Italicus. La Guerre punique. Tome I. Paris, Les Belles Lettres, 2002.

Dombart B., Kalb A. (eds, comm.). Sancti Aurelii Augustini Episcopi De civitate Dei libri XXII. Vol.2: libri XIV-XXII. Lipsiae, Teubneri, 1929.

Doutreleau L. (ed., comm.). Didyme L’Aveugle. Sur Zacharie. T. 2 et T.3. Sources Chrétiennes 84-83; Paris, Les éditions du Cerf, 1962.

Duff J. D. (transl.). Lucan. The Civil War (Pharsalia). Cambridge, Harvard University Press, 1928.

Elliger K., Rudolph W., Rüger H.P., Schenker A., Kittel R. (eds, comm.). Biblia Hebraica Stuttgartensia. Stuttgart, Deutsche Bibelgesellschaft, 52011.

Ernout A. (ed., comm.). Salluste. La Conjuration de Catilina. La Guerre de Jugurtha. Paris, Les Belles Lettres, 2012.

Feiertag J.-L (ed., comm.). S. Hieronymi presbyteri Adversus Vigilantium. Turnhout, Brepols, 2005.

Fraipont J., De Bruyne D. (eds). Sancti Aurelii Augustini Quaestionum in Heptateuchum libri VII. Locutionum in Heptateuchum libri VII. De octo quaestionibus ex Veteri Testamento. Turnholti, Brepols, 1958.

${ }^{80}$ However, Weigert (2016) does not sufficiently explain the appearance of the dipsas snake. In addition to stating that it is a curiosity (p. 129), his explanations are limited to the statement that Jerome may have made a translation error by suggesting two other poisonous creatures mentioned in the verse or

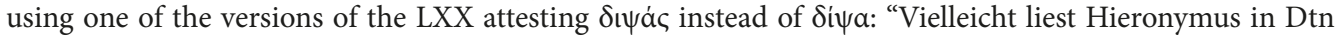
8,15 unter dem Eindruck der beiden anderen genannten Tiergattungen die Septuaginta als $\delta \iota \psi \dot{\alpha} \varsigma$ statt $\delta i \psi \alpha$,

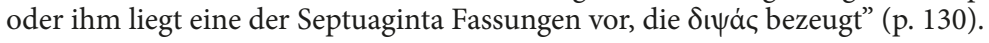


Froehlich K. Sensing the Scriptures: Aminadab's Chariot and the Predicament of Biblical. Grand Rapids Cambridge, Eerdmans, 2014.

Gilbert C. D. Five Passages in Sallust's Bellum Jugurthinum. Mnemosyne 1975, 28 (1), 67-69.

Glorie F. (ed.). S. Hieronymi presbyteri Commentariorum in Hiezechielem libri XIV. Turnholti, Brepols, 1964.

González Salinero R. Biblia y polémica antijudía en Jerónimo. Madrid, Instituto de Filología del CSIC. Departamento de Filología Bíblica y de Oriente Antiguo, 2003.

Graves M. Jerome's Hebrew Philology: A Study Based on his Commentary on Jeremiah. Leiden - Boston, Brill, 2007.

Gryson R. (ed.). Biblia sacra iuxta vulgatam versionem. Stuttgart, Deutsche Bibelgesellschaft, 52015 [2007].

Hagendahl H. Latin Fathers and the Classics: A Study on the Apologists, Jerome and other Christian Writers. Göteborg, Elander, 1958.

Hasselhoff G. K. Revising the Vulgate: Jerome and his Jewish Interlocutors. Zeitschrift für Religions- und Geistesgeschichte 2012, 64 (3), 209-221.

Hieronymus. Adversus Helvidium de Mariae virginitate perpetua. PL 23, 183-206.

Hieronymus. Commentarii in Epistolam ad Ephesios. PL 26, 439-554.

Hilberg I. (ed.). Sancti Eusebii Hieronymi Epistulae. Partes I-III: Epistulae I - CLIV. Corpus Scriptorum Ecclesiasticorum Latinorum 54-56; Vindobonae — Lipsiae, Tempsky — Freytag, 1910-1918.

Izaac H. J. (ed., comm.). Martial. Épigrammes. Tome I. Paris, Les Belles Lettres, 1930.

Jacques J.-M. (ed., comm.). Nicandre. Euvres. Tome II: Les Thériaques. Fragments iologiques antérieurs à Nicandre. Paris, Les Belles Lettres, 2002.

Kelly J. N. D. Jerome: His Life, Writings, and Controversies. New York, Harper \& Row, 1975.

Krumeich Ch. Hieronymus und die christlichen feminae clarissimae. Bonn, Habelt, 1993.

Laato A. M. Isaiah in Latin, in: L.-S. Tiemeyer (ed.) The Oxford Handbook of Isaiah. Oxford, Oxford University Press, 2021, 489-503.

Lardet P. (ed., comm.). S. Hieronymi presbyteri Contra Rufinum. Turnholti, Brepols, 1982.

Leitz Ch. Die Schlangennamen in den ägyptischen und griechischen Giftbüchern. Mainz - Stuttgart, Akademie der Wissenschaften und der Literatur, F. Steiner, 1997.

Mayhoff C. (ed.). C. Plinii Secundi Naturalis historiae libri XXXVII. T. 1-6., Lipsiae, Teubneri, 1892-1906.

Mierow C. C. (ed.). Hieronymus, Vita Malchi, in: R.E. Arnold (ed.) Classical Essays presented to J. A. Kleist. St. Louis, The Classical Bulletin - Saint Louis University, 1946, 31-60.

de Montfaucon B. Praefatio in Commentaria in Hesaiam Eusebii Pamphili. PG 24, 77-90.

Morta K. Biblical Tannin/tannim in St. Jerome’s Translation and Interpretation, in: M. Szram - M. Wysocki (eds) Studia Patristica CIII: The Bible in the Patristic Period. Leuven - Paris - Bristol, Peeters, 2021, 129-139.

Gregorius Nazianzenus. Poemata moralia. PG 37, 397-968.

Nautin P. Origène: sa vie et son cuvre. Christianisme Antique 1; Paris, Beauchesne, 1977.

Nautin P. Lactivité littéraire de Jérôme de 387 à 392. Revue de Théologie et de Philosophie. Troisième série 1983,115 (3), 247-259.

Nautin P., Hieronymus, in: G. Müller (ed.) Theologische Realenzyklopädie. Berlin, de Gruyter, 1986, 304-315.

Opelt I. San Gerolamo e i suoi maestri ebrei. Augustinianum 1988, 28, 327-338.

Oroz Reta J., Marcos Casquero M.-A. (ed.). San Isidoro de Sevilla. Etimologías. Edición bilingüe. Madrid, Biblioteca de Autores Cristianos, 2004.

Rahlfs A. (ed.). Septuaginta, id est Vetus Testamentum graece iuxta LXX interpretes. Stuttgart, Deutsche Bibelgesellschaft 1979 [1935].

Raspanti G. (ed., comm.). S. Hieronymi presbyteri Commentarii in epistulam Pauli apostoli ad Galatas. Turnhout, Brepols, 2006.

Rendsburg G. A. Diglossia in Ancient Israel, New Haven, American Oriental Society, 1990.

Richardson E. C. (ed., comm.). Hieronymus. Liber de viris inlustribus. Gennadius. Liber de viris inlustribus. Leipzig, Hinrichs'sche Buchhandlung, 1896.

Rico Ch. Le traducteur de Bethléem: le génie interprétatif de saint Jérôme à l’aune de la linguistique. Paris, Les éditions du Cerf, 2016.

Salvesen A. Symmachus in the Pentateuch. Manchester, University of Manchester, 1991.

Scheck T. P. Introduction, in: St. Jerome. Commentary on Matthew, transl. T. P. Scheck. Washington, Catholic University of America Press, 2008, 3-47.

Simonetti M. (ed.). Tyrannii Rufini opera. Turnholti, Brepols, 1961.

Sutcliffe E. F. Notes on St. Jerome's Hebrew Text. Catholic Biblical Quarterly 1949, 11, 139-143. 
Thibaut A. La révision hexaplaire de Saint Jérome, in: P. Salmon (éd.) Richesses et déficiences des anciens psautiers latins. Milano - Città del Vaticano, Abbaye Saint-Jérôme - Libreria Vaticana, 1959, 107-149.

Van den Abeele B. La tradition manuscrite des Étymologies d'Isidore de Séville. Cahiers de recherches médiévales 2008, 16, 195-205.

van Poll-van de Lisdonk M. L. (ed., comm.). Annotationes in Novum Testamentum (pars quarta). Opera omnia Desiderii Erasmi Roterodami VI/8. Amsterdam et al., Elsevier, 2003.

Weigert S. Hebraica veritas: Übersetzungsprinzipien und Quellen der Deuteronomiumübersetzung des Hieronymus. Stuttgart, Kohlhammer, 2016.

Zelzer M. (ed., comm.). Aurelius Augustinus. Contra Iulianum (opus imperfectum). Wien, Österreichische Akademie der Wissenschaften, 2004.

Ziegler J. (ed.). Eusebius Caesariensis. Der Jesajakommentar. Berlin, De Gruyter, 1975.

Zittel D. Hieronymus und Paula: Brief an eine Asketin und Mutter, in: T. Späth, B. Wagner-Hasel (Hg.) Frauenwelten in der Antike. Stuttgart, Metzler, 2000, 426-437.

Received: January 24, 2021

Accepted: June 6, 2021 


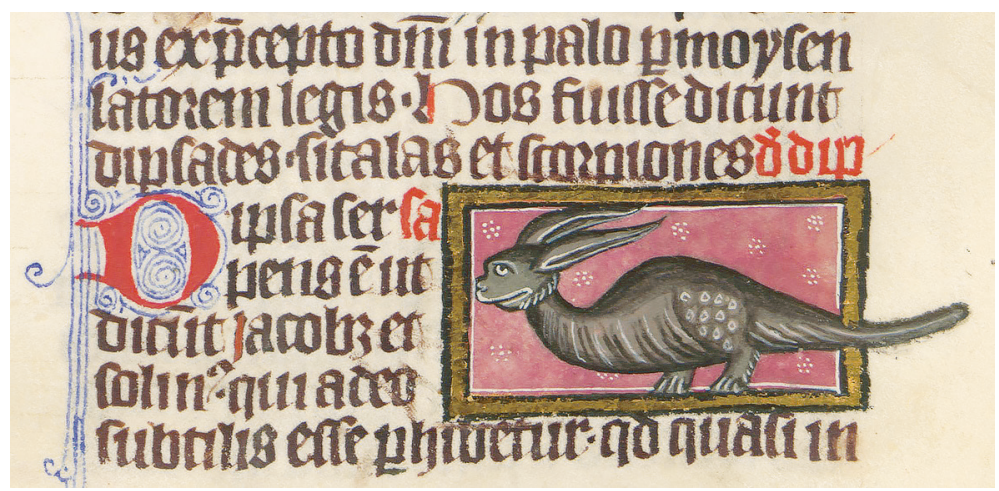

Illustration 1. The dipsas snake in the De natura rerum by Thomas of Cantimpré (Wrocław, University Library, shelf-mark: R 174 , fol. 140 r, $14^{\text {th }}$ century)

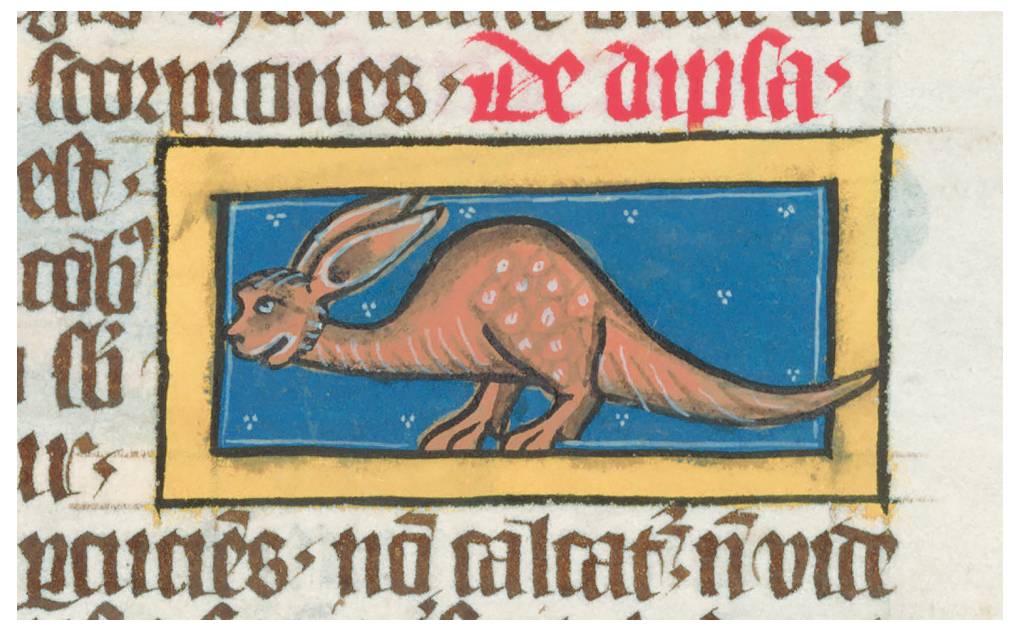

Illustration 2. The dipsas snake in the De natura rerum by Thomas of Cantimpré (Prague, National Library of the Czech Republic, shelf-mark: XIV.A. 15 , fol. 102v, ca 1375-1400) 


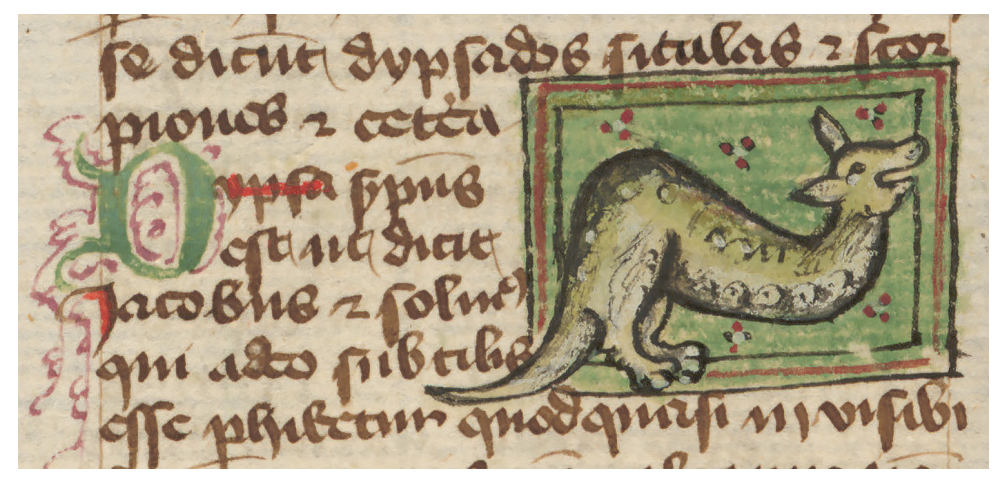

Illustration 3. The dipsas snake in the De natura rerum by Thomas of Cantimpré (Prague, National Library of the Czech Republic, shelf-mark: X. A. 4 , fol. 144r, ca 1400-1425) 